Technological University Dublin

ARROW@TU Dublin

2005-10

\title{
Comparing the Gut Flora of Irish Breastfed and Formula-fed Neonates Aged Between Birth and 6 Weeks Old
}

\author{
Gordon Cooke \\ Technological Unviersity Dublin, gordon.cooke@tudublin.ie \\ John Behan \\ Technological University Dublin, john.behan@tudublin.ie \\ Nicola Clarke \\ National Maternity Hospital, Dublin
}

See next page for additional authors

Follow this and additional works at: https://arrow.tudublin.ie/ittsciart

Part of the Microbiology Commons

\section{Recommended Citation}

Cooke, G., Behan, J., Clarke, N., Gorman, W. and Costello, M. Comparing the gut flora of Irish breastfed and formula-fed neonates aged between birth and 6 weeks old. Microbial Ecology in Health and DiseaseJan 2005, Vol. 17, No. 3, Pages 163-168 (doi:10.1080/08910600500430664)

This Article is brought to you for free and open access by the School of Science and Computing at ARROW@TU Dublin. It has been accepted for inclusion in Articles by an authorized administrator of ARROW@TU Dublin. For more information, please contact

arrow.admin@tudublin.ie, aisling.coyne@tudublin.ie, gerard.connolly@tudublin.ie.

Funder: PDRSP Strand 1 and Technological University

Dublin

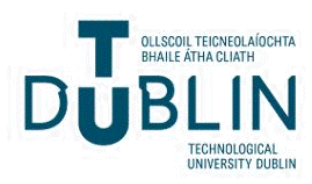




\section{Authors}

Gordon Cooke, John Behan, Nicola Clarke, Winifred Gorman, and Mary Costello

This article is available at ARROW@TU Dublin: https://arrow.tudublin.ie/ittsciart/28 


\title{
Comparing the Gut Flora of Irish Breast and
}

\section{Formula Fed Neonates aged between Birth and 6}

\section{Weeks Old}

\author{
Gordon Cooke B.Sc. ${ }^{1}$, John Behan ${ }^{1}{ }^{*}$ M.B.S., M.Sc., \\ Nicola Clarke ${ }^{2}$ M.Sc. RM. IBCLC, Winifred Gorman ${ }^{2}$ M.D., Mary Costello ${ }^{1 *}$ \\ Ph.D. \\ ${ }^{1}$ Institute of Technology Tallaght, Dublin, Ireland. \\ ${ }^{2}$ National Maternity Hospital, Dublin, Ireland.
}

Correspondence and Reprint requests to (*M.C/J.B) Department of Applied Science, Institute of Technology Tallaght, Old Blessington Road, Tallaght, Dublin 24, Ireland.

\begin{tabular}{ll} 
Abstract Word Count: & $\mathbf{1 7 0}$ \\
\hline Total Word Count: & $\mathbf{2 4 1 4}$ \\
\hline Number of Figures: & 2 \\
\hline Number of Tables: & 4
\end{tabular}




\begin{abstract}
Ireland has one of the lowest breastfeeding rates in the developed world. A gut flora consisting of high levels of the bacteria Bifidobacteria and Lactobacilli is regarded as a healthy gut. These bacteria are reported to impart beneficial health properties to humans. This project looked at the establishment of eight selected representative bacterial groups of the gut flora at three time points in the 0-6 week range, differentiating between breast fed and formula fed babies. Microbiological methods were used to specifically enumerate Lactobacilli sp., Bifidobacteria sp., Enterococci sp., Staphylococci sp., Bacteroides sp., Clostridia sp. and coliforms present in the gut. The data indicated major trends present, including the fact that Bifidobacteria sp. and Lactobacilli sp. were more prevalent in the gut flora of breast fed neonates whereas E.coli and Enterococci sp. were more prevalent in the gut flora of formula fed neonates. The higher prevalence of Bifidobacteria and Lactobacilli, which are often incorporated into probiotic foods, in Irish breast fed neonates thus re-enforces the advantages of breastfeeding over formula feeding.
\end{abstract}

\title{
Key Words
}

Gut flora, neonate, breastfeeding, formula feeding, probiotics, Bifidobacteria, Lactobacilli. 


\section{Introduction}

'You are what you eat', as the saying goes, and at no point in life is this more relevant than at birth. Diet is a major dictator of the health and wellbeing of every human. Modification of our diet using probiotics is now becoming more common, with companies selling products that contain bacteria with reported beneficial properties ${ }^{1,2,3}$ including Bifidobacteria sp. and Lactobacilli $\mathrm{sp}^{4,5}$. These bacteria are well documented as preventing diarrhoea and colon cancer, stimulating the immune system, and inhibiting the growth of toxin producing organisms such as Clostridia difficle, Escherichia coli, Salmonella sp. and Shigella sp. ${ }^{6,5,7,8,9}$. Several previously reported studies have examined the effect of the feeding regime of newborn infants on the establishment and composition of the gut flora and these have shown that there are differences between the gut flora of a breast fed neonate and a formula fed neonate ${ }^{10,11,12,13,14,15}$. Despite the fact that these studies have indicated that breastfeeding provides a more beneficial bacterial composition in the gut for the infant than formula feeding, Ireland has one of the lowest breast feeding initiation rates in the developed world, at $35 \%$ compared with our nearest neighbour, the UK, at $70 \%$ and Scandinavian countries where the rate can be as high as $95 \%{ }^{16}$. The study presented in this paper is the first study to examine the Irish neonatal gut in the 06 week age group, to establish if a statistically significant link could be found in the percentage presence and dominance of several bacterial groups which occur in the gut flora over the selected time period, with the aim to provide further evidence of the beneficial effect of breast milk. 


\section{Materials and Methods}

Subject selection. The study was approved by the ethics committee of the National Maternity Hospital, Holles Street, Ireland. Signed consent was obtained from all informed parents prior to the inclusion of their infants in this study. All babies were of normal vaginal delivery and were from four different wards within the one hospital. A random selection of 105 infants varying in age from zero to six weeks were each sampled once during the study, with 49 being exclusively fed breast milk and 56 being exclusively given formula milk in the period from birth to sampling.

Collection of specimens. Samples were collected at several time points between the years $2001 \& 2002$. Fresh faecal samples were collected in the nursery from the neonates' nappies using sterile swabs, during the first 5 days of life. Faecal samples from 6 week old infants were obtained by swabbing nappies which had been soiled either immediately preceding the visit and were then provided in sealed plastic bags by the parent, or alternatively were freshly soiled during the hospital check-up visit. All swabs were placed in sterile Aimes medium for transport back to the laboratory where they were frozen at $-70^{\circ} \mathrm{C}$ within three hours of sampling. Recovery rates were determined to ensure the viability of cells throughout the storage period.

Culture and identification of bacteria. The specimens were thawed out at room temperature before serial tenfold dilutions were performed from $10^{-1}$ to $10^{-7}$ in sterile Ringers solution. $0.2 \mathrm{mls}$ of each dilution was applied to duplicate plates 
of each selective culture media and distributed over the surface using a sterile spreader. The bacteria selected for the study, the culture media and incubation conditions are summarised in Table 1.

After incubation, as indicated in Table 1, plates which contained between 30 and 300 colonies were enumerated. To ensure that the correct colonies were being enumerated and identified, picks of each different colony morphology type were taken and analysed by Gram stain and then stored at $-70^{\circ} \mathrm{C}$ in Tryptic Soy Agar and 10\% glycerol for later analysis by API system (bioMérieux). Bacterial counts were initially expressed as colony forming units $(\mathrm{cfu}) / \mathrm{ml}$. In order to compare bacterial composition between swabs that varied in faecal matter content, a percentage presence was calculated for each bacterial group relative to the total count for each bacterial swab. An independent " $\mathrm{t}$ " test was used to statistically analyse the data gathered. A $p$ value of $<0.05$ was considered to be statistically significant. 


\section{Results}

The number of samples that tested positive for the selected bacteria in both feeding regimes over the three different time periods was determined (Table 2). The average percentage presence calculated for each bacterial group studied in both feeding regimes at the three different time points is presented in Table 3 . The rate of dominance of each bacterial group, in samples that tested positive for the particular bacterial species, is presented in Table 4 .

In 0-1 day old breast and formula fed neonates no statistically significant differences were determined between the numbers of samples testing positive for each bacterial species. It did appear that the gut flora of the breast fed neonate developed quicker than that of the formula fed neonate, in that more breast fed neonates tested positive for the selected groups of bacteria than formula fed neonates. Staphylococci sp. were found in $58 \%$ of all breast fed neonates tested as opposed to only $25 \%$ of all formula fed neonates tested (Table 2). The $p$ value for this result was 0.08 indicating a trend which is almost statistically significant.

In 2-5 day old neonates (Table 2) Bifidobacteria sp. were more likely to be present in breast fed neonates $(71 \%)$ than formula fed neonates $(48 \%)$. This result, while not statistically significant, $(p=0.16)$ shows a strong trend. Bifidobacteria sp. were also present on average, in higher percentages (Table 3) in breast fed neonates (36\%) compared to formula fed neonates (19\%). Although this latter result was not statistically significant, the removal of two "outliers" 
(Figure 1) from the total of 27 formula fed neonates tested resulted in a statistically significant $p$ value of 0.03 .

Other trends observed in the analysis of 2-5 day old neonates (Table 3) were that Bacteroides sp. had a higher average percentage presence in breast fed neonates $(7 \%)$ compared with formula fed neonates $(0.08 \%)$ with a $p$ value of 0.16. In addition, Lactobacilli sp. were more likely to be dominant (Table 4) when present in formula fed neonates (43\%) compared to breast fed neonates $(0 \%)$ with a $p$ value of 0.15

Enterococci sp. tested positive in more 6 week old formula fed neonates (94\%) compared to breast fed neonates $(75 \%)$ of the same age (Table 2) with a $p$ value of 0.13 . Enterococci $\mathrm{sp}$. were also more likely to be dominant $(p=0.12)$ in the 6 week old formula fed neonates giving a value of $17 \%$ as opposed to $0 \%$ in breast-fed infants (Table 4). E.coli were also more likely to be present in higher average percentages in 6 week old formula fed neonates (20\%) compared to breast fed neonates $(7 \%)$ of the same age (Table 3 ) with a low $p$ value of 0.13 , indicating a possible underlying trend. The average percentage presence of Lactobacilli sp. was higher in 6 week old breast fed neonates at $25 \%$ as compared to $7 \%$ in formula fed neonates which gave a $\mathrm{p}$ value of 0.1 . However, with the removal of one particular outlying value (Figure 2) from the total of 17 formula fed data points, the $p$ value became statistically significant $(p=0.03)$. In addition, this study indicated that Lactobacilli sp., when present in 6 week old neonates (Table 4), were more likely to be dominant $(p=0.15)$ in breast fed neonates $(45 \%)$ compared with formula fed neonates $(17 \%)$. 


\section{Discussion}

Random sampling of infants of various age profiles set out to analyse the selected bacterial groups known to comprise a major proportion of the neonatal intestinal gut flora (Fuller, 1992). While several other species are known to colonise the gut at lower levels, the study was designed to only assess the predominant neonatal gut flora in the Irish infants. The provision of updated additional evidence supporting the beneficial effects of breast feeding will aid in promoting the uptake rates for exclusive breast milk feeding regimes This study showed that by day 5 the faecal floras of both feeding regimes are becoming well established. The results presented, indicate the differences between the gut flora of breast and formula fed neonates immediately from the introduction of feeds and that these differences continue to be seen at least until the 6 week point examined in this study.

Staphylococci sp. were found to be testing positive in more 0-1 day old breast fed neonates than formula fed neonates $(p=0.08)$ in this study. This result

was similar to the findings of another study ${ }^{14}$ where all five of the 1 day old breast fed neonates studied had been colonised with Staphylococci sp., compared to just 3 out of 6 formula fed neonates. The close contact between mother and child during feeding presumably results in transfer of this bacterium from the mothers' skin to the child.

The breast fed neonates in this study were dominated by the presence of Bifidobacteria sp. at both the 2-5 day old and the 6 week old time periods. 
Previous studies ${ }^{13,14,15}$ have also reported Bifidobacteria sp. to be present in higher amounts in breast fed neonates compared to formula fed neonates at the fifth day of life.

The considerably higher Bifidobacterial level in infants as young as 2 days of age is earlier than reported in previous studies. However, in the studies by Lundequist ${ }^{12}$ and Yoskioka ${ }^{14}$ it was reported that by the third week and fifth week of life the bacterial group was present in higher amounts in formula fed neonates. Oligosaccharides naturally present in breast milk have been shown to stimulate the growth of Bifidobacteria $\mathrm{sp}^{18,19}$.

Another study in $2002^{19}$ also found that human milk provides peptides that are highly stimulating to Bifidobacteria sp., are present in much lower levels in bovine milk, which could provide a partial explanation for the higher levels of Bifidobacteria sp. being found in breast fed neonates compared to formula fed neonates.

In agreement with the work of Rubaltelli et al. ${ }^{13}$, Lundequist et $a .^{12}$, and Yoshioka et al. ${ }^{14}$, Bacteroides sp. were found to be present in higher average percentages in 2-5 day old breast fed neonates, than for formula-fed infants with a lower $p$ value of 0.16 (Table 3). Lactobacilli sp., as with Bifidobacteria sp., were found more likely to be the dominant bacterial group when present in $2-5$ day old breast fed neonates compared to formula fed neonates of the same age, in agreement with previously reported studies ${ }^{12,13,14}$. By the sixth week Lactobacilli sp. when detected, were more likely to be dominant and on average were present in higher percentages in breast fed neonates compared to formula fed neonates. 
This result was similar to the findings of Lundequist ${ }^{12}$, and Yoshioka ${ }^{14}$ but is not in agreement of the findings of Benno ${ }^{10}$. Breast milk has recently been shown to be a possible source of Lactobacilli sp. in a study by Martin ${ }^{22}$. The finding that Enterococci sp. and E.coli are more likely to be present in higher levels in 6 week old formula fed neonates compared to breast fed neonates is similar to the findings of previous studies ${ }^{12,13,14}$.

The composition of the complex ecosystem that forms the human gut flora is influenced by several factors. This study, which examined the effect of breast milk versus formula milk in the evolving gut of a newborn infant, strongly suggests that breast milk plays an important role in encouraging the growth and dominance of healthy bacteria such as the Lactobacilli and Bifidobacteria in the neonatal gut. Breast milk is composed of many components that inhibit diseasecausing bacteria such as Clostridia sp. and which also play a role in encouraging the growth of healthy bacteria like the Lactobacilli and Bifidobacteria ${ }^{20}$. These latter bacteria have been shown to be less likely to cause disease and are reported to aid the immune system by either inhibiting the growth of disease-causing organisms by lowering the $\mathrm{pH}$ of the gut or by producing anti-microbials ${ }^{10}$. These organisms have been shown to inhibit the growth of Escherichia coli, Salmonella enteritidis and Clostridium jejuni ${ }^{21}$ all of which are common enteropathogens. In contrast, the gut flora of the formula fed neonate seems to be dominated more by E.coli and Enterococci, bacteria which would generally not be considered as contributing to a healthy gut. 


\section{Conclusion}

Despite the fact that the study could not follow the same infants throughout the 0-6 week period the results obtained are similar to those of studies that did. Overall, this study's results supports the findings of studies done in other countries and indicates that exclusive breastfeeding of Irish neonates offers the type of healthy gut bacteria considered desirable to humans throughout life. It is also hoped that the publication of this study's findings will help improve breast feeding rates in Ireland. 


\section{Acknowledgements}

This study would like to acknowledge the support from the Department of Education PDRSP Strand 1 funding together with Seed and PhD continuance funding from the Institute of Technology Tallaght, Ireland. The authors would also like to thank Martina O'Neill of the N.M.H., Ireland; Brian Carr for his assistance with the statistical analysis; and finally the mothers and their newborns of the N.M.H. Ireland. 


\section{References}

1. Saarela M, Lahteenmaki L, Crittenden R, Salminen S, Matilla-Sandholm

T. Gut bacteria and health foods- The European perspective. International Journal of Food Microbiology 2002; 78:99-117.

2. Schiffrin EJ, Blum S. Food processing: Probiotic micro-organisms for beneficial foods. Current Opinion in Biotechnology 2001; 12:499-502.

3. Shah NP. Probiotic bacteria: Selective enumeration and survival in dairy foods. Journal of Dairy Science 2000; 83(4):894-907.

4. Collins DM, Gibson GR. Probiotics, prebiotics and synobiotics: Approaches the microbial ecology of the gut. American Journal of Clinical Nutrition 1999; 69:1052-7.

5. Gill HS. Stimulation of the immune system by lactic cultures. International Dairy Journal 1998; 8:535-44.

6. Fooks LJ, Fuller R, Gibson GR. Prebiotics, probiotics and human gut microbiology. International Dairy Journal 1999; 9:53-61.

7. Hirayama K, Rafter J. The role of probiotic bacteria in cancer prevention. Microbes and Infection 2000; 2(6):681-6. 
8. Ouwehand AC, Kirjavainen PV, Shortt C, Salminen S. Probiotics: Mechanisms and established effects. International Dairy Journal 1999; 9:43-52.

9. Salminen S, Ouwehand AC, Isolauri E. Clinical applications of probiotic bacteria. International Dairy Journal 1998; 8:563-72.

10. Benno Y, Sawada K, Mitsuoka T. The intestinal microflora of infants; Composition of faecal flora in breast-fed and bottle-fed infants. Immunology 1984; 28(9):975-86.

11. Kleesen B, Bunke H, Tovar K, Noack J, Sawatzki G. Influence of two infant formulas and human milk on the development of the faecal flora in newborn infants. Acta Paediatrics 1995; 84:1347-56.

12. Lundequist B, Nord CE, Winberg J. The composition of the faecal microflora in breast fed and bottle fed infants from birth to eight weeks. Acta Paediatrics Scandinavia 1985; 74(1):45-51.

13. Rubatelli, Firmino F, Biadaioli R, Pecile P, Nicoletti P. Intestinal flora in breast and bottle fed infants. Journal of Perinatel Medicine 1998; 26:18691. 
14. Yoshioka H MD, Iseki K MD, Fujita K MD. Development and differences of intestinal flora in the neonatal period in breast and bottle fed infants. Pediatrics 1983; 72(3):317-21.

15. Stark PL, Lee A. The microbial ecology of the large bowel of breast fed and formula fed infants during the first year of life. Journal of Medical Microbiology 1982; 15(2):189-203.

16. Loftus BG, Loh NR, Kelleher CC, Long S. Can we increase breast feeding rates? Irish Medical Journal 1997; 90(3):1-4.

17. Lonnerdal B. Breast milk: A truly functional food. Nutrition 2000; 16(7/8):509-11.

18. Emmett PM, Rogers IS. Properties of human milk and their relationship with maternal nutrition. Early Human Development 1997; 49:7-28.

19. Lievin V, Peiffer I, Hudault S, Rochat F, Brassart D, Neeser JR, Servin AL. Bifidobacteria strains from resident infant human gastrointestinal microflora exert antimicrobial activity. Gut 2000; 47(5):646-52.

20. Liepke C, Adermann K, Raida M, Magert HJ, Forssmann WG, Zucht HD. Human milk provides peptides highly stimulating the growth of Bifidobacteria. European Journal of Biochemistry 2002; 269(2):712-8. 
21. Fooks LJ, Gibson GR. In vitro investigations of the effects of probiotics and prebiotics on selected human intestinal pathogens. FEMS Microbiology Ecology 2001; 1310:1-9.

22. Martin R, Langa S, Reviriego C, Jimenez E, Marin M, Xaus J, Fernandez L, Rodriguez JM. Human milk is a source of lactic acid bacteria for the infant gut. The Journal of Pediatrics 2003; 143:754-8.

23. Fuller R. Probiotics: The scientific basis: Chapman and Hall; 1992. 
Table I. Culture media and incubation conditions.

\begin{tabular}{|c|c|c|c|}
\hline Culture Medium & $\begin{array}{c}\text { Bacterial group } \\
\text { isolated }\end{array}$ & Temperature & Atmosphere \\
\hline Eosin Methylene Blue & $\begin{array}{c}\text { Escherichia coli and } \\
\text { other members of } \\
\text { the } \\
\text { Enterobacteriaceae } \\
\text { family }\end{array}$ & $37^{\circ} \mathrm{C}$ & Aerobic \\
\hline Rogosa Agar & Lactobacillisp. & $37^{\circ} \mathrm{C}$ & Anaerobic \\
\hline $\begin{array}{c}\text { Bacteroides Bile Aesculin } \\
\text { Agar }\end{array}$ & Bacteroides sp. & $37^{\circ} \mathrm{C}$ & Anaerobic \\
\hline Baird Parker Media & Staphylococci sp. & $37^{\circ} \mathrm{C}$ & Aerobic \\
\hline Reinforced Clostridial Agar & Clostridia sp. & $37^{\circ} \mathrm{C}$ & Anaerobic \\
\hline $\begin{array}{c}\text { Reinforced Clostridial Agar } \\
\text { with Analine Blue }\end{array}$ & Bifidobacteria sp. & $37^{\circ} \mathrm{C}$ & Anaerobic \\
\hline Slanetz and Bartley & Enterococci sp. & $44^{\circ} \mathrm{C}$ & Aerobic \\
\hline
\end{tabular}


Table II. Number of samples testing positive in the gut flora of 0-1, 2-5 days and 6 Week old breast and formula fed neonates.*

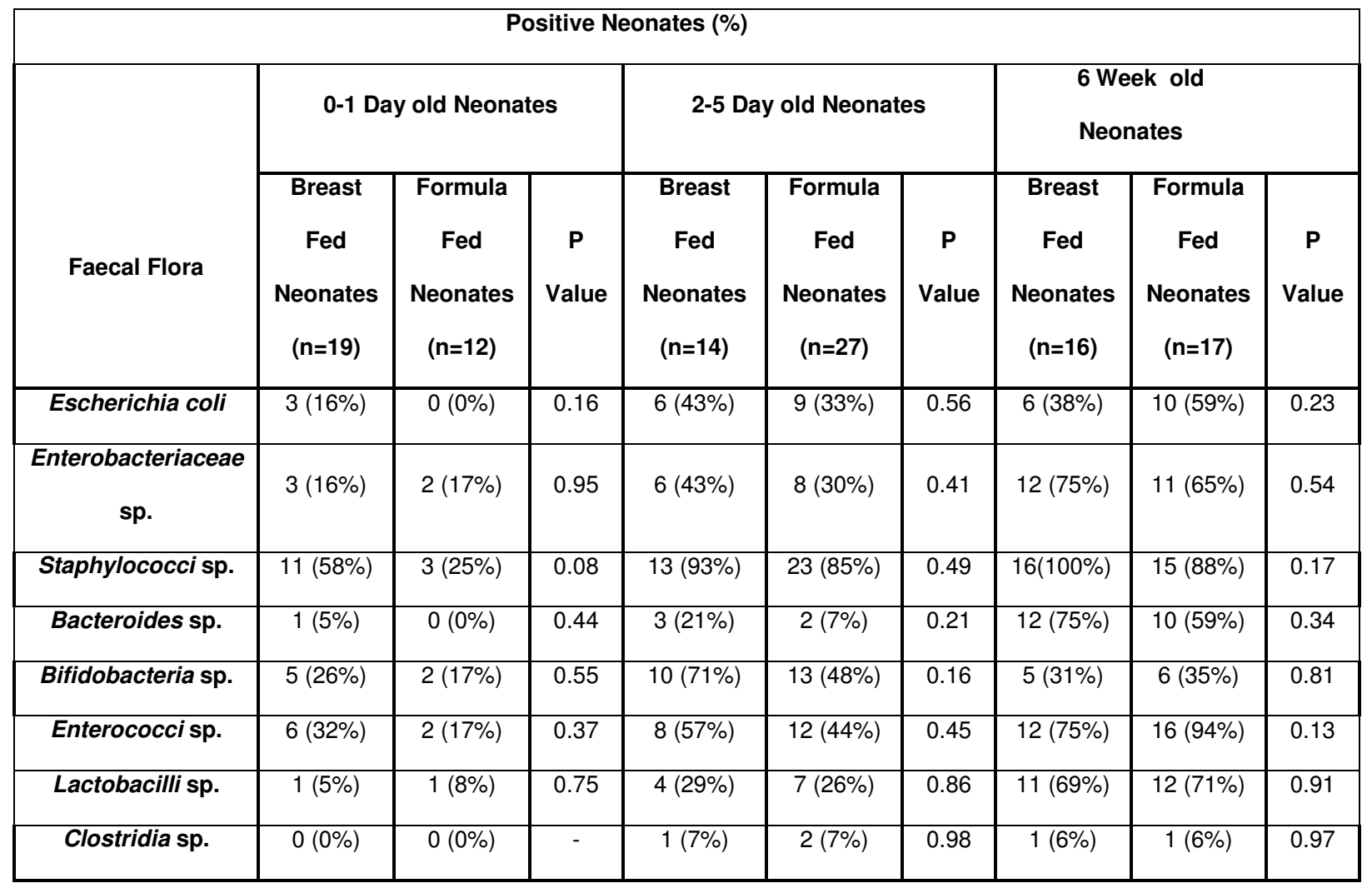

* The total number of samples tested is indicated by ' $n$ '. The number of samples testing positive is given in each column with the associated percentage value given in brackets. ' $p$ ' values were calculated using the independent ' $\mathrm{t}$ ' test. 
Table III. Average percentage presence of each bacterial group in the gut flora of 0-1, 2-5 days and 6 Week old breast and formula fed neonates.*

\begin{tabular}{|c|c|c|c|c|c|c|c|c|c|}
\hline & \multicolumn{7}{|c|}{ Average Percentage Presence (\%) } \\
\hline \multirow{2}{*}{ Faecal Flora } & \multicolumn{2}{|c|}{ 0-1 Day old Neonates } & \multicolumn{2}{|c|}{ 2-5 Day old Neonates } & \multicolumn{2}{c|}{ 6 Week old Neonates } \\
\cline { 2 - 10 } & Breast & Formula & P & Breast & Formula & P & Breast & Formula & P \\
\hline E.coli & $7 \%$ & $0 \%$ & 0.32 & $9 \%$ & $19 \%$ & 0.36 & $7 \%$ & $20 \%$ & 0.13 \\
\hline Enterobacteriaceae & $4 \%$ & $1 \%$ & 0.53 & $7 \%$ & $16 \%$ & 0.36 & $16 \%$ & $22 \%$ & 0.48 \\
\hline sp. & & & & & & & & & \\
\hline Staphylococci sp. & $30 \%$ & $14 \%$ & 0.2 & $18 \%$ & $20 \%$ & 0.75 & $10 \%$ & $5 \%$ & 0.36 \\
\hline Bifidobacteria sp. & $8 \%$ & $4 \%$ & 0.45 & $36 \%$ & $19 \%$ & 0.16 & $14 \%$ & $20 \%$ & 0.5 \\
\hline Enterococci sp. & $9 \%$ & $7 \%$ & 0.43 & $20 \%$ & $12 \%$ & 0.39 & $7 \%$ & $15 \%$ & 0.12 \\
\hline Lactobacilli sp. & $5 \%$ & $0.10 \%$ & 0.66 & $2 \%$ & $11 \%$ & 0.28 & $25 \%$ & $7 \%$ & 0.1 \\
\hline Clostridia sp. & $0 \%$ & $0 \%$ & - & $0.60 \%$ & $1.20 \%$ & 0.67 & $1.20 \%$ & $0.40 \%$ & 0.53 \\
\hline
\end{tabular}

* Percentage presence was calculated for each bacterial group relative to the total count for each bacterial swab. ' $p$ ' values were calculated using the independent ' $\mathrm{t}$ ' test. 
Table IV. Comparison of dominance, within the number of samples

testing positive for each bacterial group, in breast and formula fed neonates

aged 0-1, 2-5 days and 6 Weeks old.*

\begin{tabular}{|c|c|c|c|c|c|c|c|c|c|}
\hline \multirow[b]{3}{*}{ Faecal Flora } & \multicolumn{9}{|c|}{ Dominance (\%) } \\
\hline & \multicolumn{3}{|c|}{ 0-1 Day Old Neonates } & \multicolumn{3}{|c|}{ 2-5 Day Old Neonates } & \multicolumn{3}{|c|}{6 Week Old Neonates } \\
\hline & $\begin{array}{c}\text { Breast } \\
\text { Fed } \\
\text { Neonates } \\
(n=19)\end{array}$ & $\begin{array}{c}\text { Formula } \\
\text { Fed } \\
\text { Neonates } \\
(n=12)\end{array}$ & $\begin{array}{c}\mathbf{P} \\
\text { Value }\end{array}$ & $\begin{array}{c}\text { Breast } \\
\text { Fed } \\
\text { Neonates } \\
(n=14)\end{array}$ & $\begin{array}{c}\text { Formula } \\
\text { Fed } \\
\text { Neonates } \\
(n=27)\end{array}$ & $\begin{array}{c}\mathbf{P} \\
\text { Value }\end{array}$ & $\begin{array}{c}\text { Breast } \\
\text { Fed } \\
\text { Neonates } \\
(n=16)\end{array}$ & $\begin{array}{c}\text { Formula } \\
\text { Fed } \\
\text { Neonates } \\
(n=17)\end{array}$ & $\begin{array}{c}\text { P } \\
\text { Value }\end{array}$ \\
\hline Escherichia coli & $1 / 3(33 \%)$ & $0(0 \%)$ & - & $2 / 6(33 \%)$ & $5 / 9(56 \%)$ & 0.43 & $0 / 6(0 \%)$ & $4 / 10(40 \%)$ & 0.08 \\
\hline $\begin{array}{c}\text { Enterobacteriaceae } \\
\text { sp. }\end{array}$ & $1 / 3(33 \%)$ & $0 / 2(0 \%)$ & 0.5 & $1 / 6(17 \%)$ & 4/8 (50\%) & 0.22 & $2 / 12(13 \%)$ & $4 / 11(36 \%)$ & 0.3 \\
\hline Staphylococci sp. & $6 / 11(55 \%)$ & $2 / 3(67 \%)$ & 0.73 & $2 / 13(15 \%)$ & $6 / 23(26 \%)$ & 0.47 & $1 / 16(16 \%)$ & $0 / 15(0 \%)$ & 0.34 \\
\hline Bacteroides sp. & $0 / 1(0 \%)$ & $0(0 \%)$ & - & $1 / 3(33 \%)$ & $0 / 2(0 \%)$ & 0.5 & $4 / 12(33 \%)$ & $1 / 10(10 \%)$ & 0.21 \\
\hline Bifidobacteria sp. & $1 / 5(20 \%)$ & $0 / 2(0 \%)$ & 0.58 & $6 / 10(60 \%)$ & $6 / 13(46 \%)$ & 0.53 & $4 / 5(80 \%)$ & $4 / 6(67 \%)$ & 0.66 \\
\hline Enterococci sp. & $2 / 6(33 \%)$ & $1 / 2(50 \%)$ & 0.72 & $3 / 8(38 \%)$ & $3 / 12(25 \%)$ & 0.57 & $0 / 12(0 \%)$ & $3 / 16(17 \%)$ & 0.12 \\
\hline Lactobacilli sp. & $1 / 1(100 \%)$ & $0 / 1(0 \%)$ & - & $0 / 4(0 \%)$ & $3 / 7(43 \%)$ & 0.15 & $5 / 11(45 \%)$ & $2 / 12(17 \%)$ & 0.15 \\
\hline Clostridia sp. & $0(0 \%)$ & $0(0 \%)$ & - & $0 / 1(0 \%)$ & $0 / 2(0 \%)$ & - & $0 / 1(0 \%)$ & $0 / 1(0 \%)$ & - \\
\hline
\end{tabular}

* The number of samples which showed dominance for each bacterial group tested is represented as a fraction of the total number of samples which tested positive for that particular species. The percentage value is given in brackets. ' $p$ ' values were calculated using an independent ' $t$ ' test. 
Figure I. Percentage presence of Bifidobacteria sp. in 2-5 day old breast and formula fed neonates.*

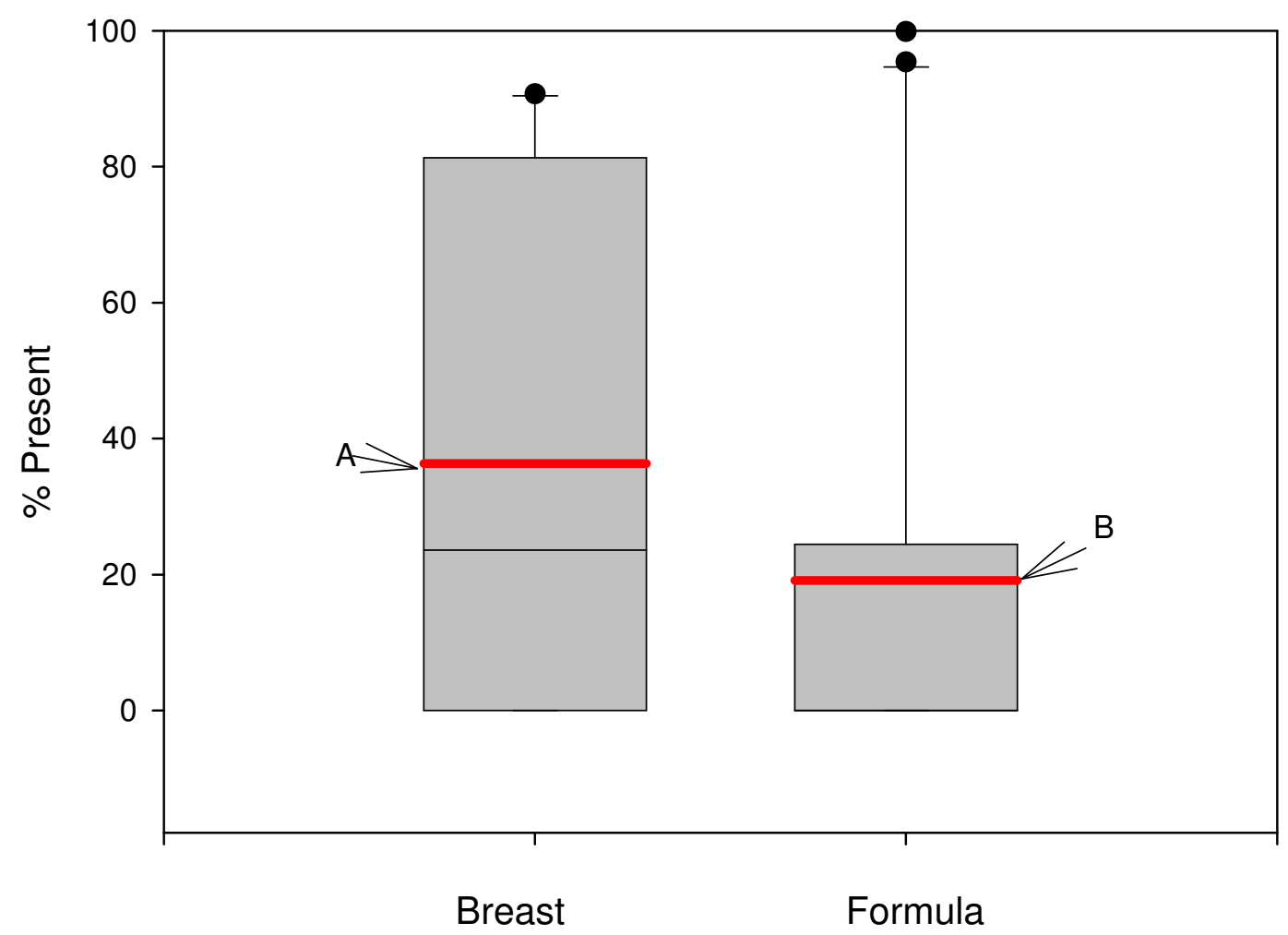


* Figure I shows the percentage presence range of Bifidobacteria sp. in 2-5 day old breast and formula fed neonates. The average percentage presence is indicated for breast-fed (A) and formula-fed (B) infants. 
Figure II. Percentage presence of Lactobacilli sp. in 6 week old breast and formula fed neonates.*

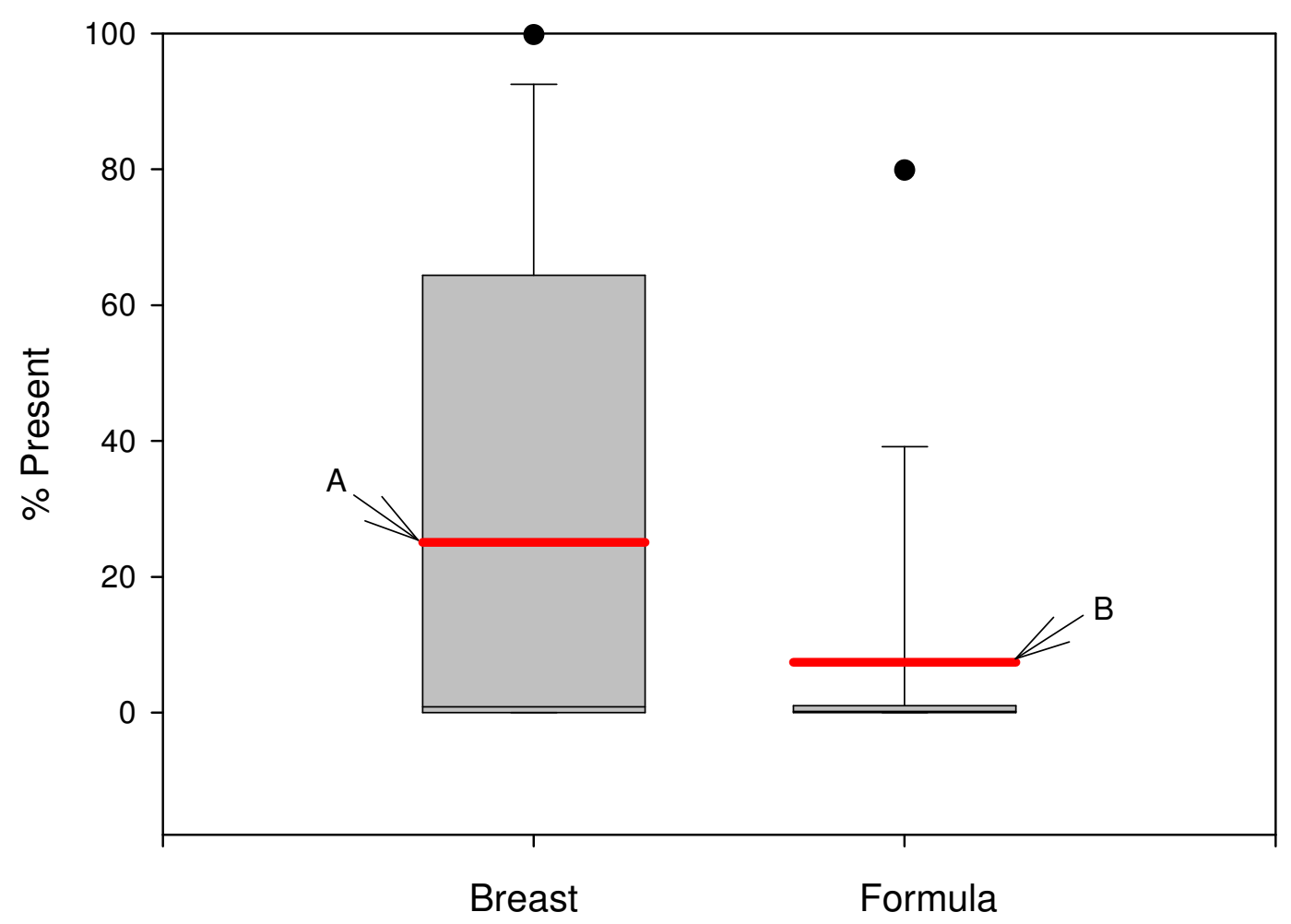


* Figure II shows the percentage presence range of Lactobacilli sp. in 6 week old breast and formula fed neonates. The average percentage presence for breast-fed infants (A) and formula-fed infants (B) is indicated. 